\section{Activists attack in Arizona}

\section{Tucson}

ANIMAL rights activists broke into four buildings at the University of Arizona on 3 April and set two fires, vandalized laboratories and kidnapped 1,000 animals to protest against the use of animals in research. University officials said that structural damage amounted to $\$ 110,000$ and estimates of the total damage go as high as $\$ 250,000$.

In press releases left at local newspaper offices and radio and television stations, the Animal Liberation Front claimed responsibility for the arson and damage. A fire in a rooftop laboratory of a five-storey pharmacy-microbiology building gutted two rooms and damaged two others, causing a total of $\$ 90,000$ damage. That fire took an hour and 46 firefighters to get under control.

A second fire was started in the crawl space under the small house containing the animal resources administrative offices and caused $\$ 10,000$ damage. Clyde S. Card, director of the Arizona Diagnostic Laboratory, said that about $\$ 125,000$ damage had been done to that laboratory's autopsy room and three veterinary science laboratories.

Vandals also smashed windows and ransacked laboratories in a neighbouring building and in another a block north of the pharmacy-microbiology building. They spray-painted slogans including "Nowhere is safe", "We shall return", "You are killers" and "Torture teaches nothing" in red on the walls and floors. Pet food was strewn over one basement.

The group's statement said that a thousand animals were liberated as an act of mercy and compassion for the individual animal victims and that laboratories were damaged to protest against vivisection. The statement claimed that the action was part of an international campaign against misguided efforts by the scientific and medical industry.

'People for the Ethical Treatment of Animals', an animal rights organisation based in Washington, DC, later provided television stations with a video of the break-in, showing black-hooded individuals loading animals into boxes and smashing windows with hammers. The group took about 1,000 mice, 50 rats, 175 rabbits, 4 frogs and several guinea pigs. According to the animal activists, the animals were being placed "in good homes around the country where they will live free from the invasive curiosity of researchers and vivisectionists".

About 30 of 340 mice taken from one building were infected with Cryptosporidium, a protozoa that causes severe diarrhoea, according to Charles Sterling, a professor of veterinary science.

The mice were being used in a study supported by the US Environmental Protection Agency to test the effectiveness of disinfectants against this waterborne parasite. Those who handle the mice may suffer from severe diarrhoea for two to four weeks.

Other affected work included genetic studies of heat stress, studies of the longterm effects of selenium-deficient diets, research on a vaccine for swine dysentery and studies of the effect of diet on protein metabolism. Scientists involved estimated that the loss of animals set the projects back months, and perhaps years.

\section{Boston}

Wiти recommendations from an advisory panel due this week, the city of Cambridge, Massachusetts, moves one step closer to passing the first local ordinance in the United States to provide municipal control over the care and treatment of laboratory animals. While it is still too early to know precisely what provisions the law will entail, it is likely that the city council will pass legislation this spring.

The new recommendations come from a panel established by the city council in the autumn of 1987 to evaluate the treatment of laboratory animals at facilities in Cambridge. Among those facilities are several belonging to the Massachusetts Institute of Technology (MIT).

The three-member panel, which includes a local veterinarian and representatives from the scientific community and animal rights groups, found no instances of cruelty or abuse of animals in Cambridge laboratories. But the group is still split over the adequacy of existing regulatory mechanisms in the city.

Because of the disagreement, the panel delayed release of its recommendations to the city council. But the pressure is on for city officials to act on the issue. Under consideration are provisions which would give a local animal commission the power to uphold "the community's ethical standards for the use of animals in experiments". The local authority would investigate alleged violations of local standards for the care of laboratory animals and fines to research institutions that failed to comply. A further provision to be considered by the city council would require researchers who handle animals in laboratories in Cambridge to take a course from the local animal commission on the new standards.

John Moses, an MIT physician who heads the university's animal care committee, represented the scientific community on the advisory panel. He stresses
The Animal Liberation Front group may have been helped by people inside the university as they appear to have known where and how the animals were housed, according to Michael Cusanovich, University of Arizona vice-president for research. The group is thought to have broken into one building by forcing open a vent. Police were not sure how the group gained access to the other buildings. The Federal Bureau of Investigation is also involved in the case.

In January, animal activists claimed responsibility for taking seven dogs used in heart research at the Tucson Veterans Administration Hospital.

Elizabeth Pennisi

\title{
Municipal law on its way
}

that the panel's lack of evidence of animal abuse argues against the need for local legislation. But he believes the panel is "very close" to making recommendations that all three representatives can agree upon. The recommendations should give a clear guide as to the severity of the city council's actions.

The council has already taken interim action. Nearly two years ago, when the advisory panel was formed, it banned outright within city limits the use of two common animal toxicity tests, the Draize test and the LD 50 test. Animal rights groups have already proposed strong city legislation to regulate practices involving laboratory animals; the panel's forthcoming recommendations are seen as offering the potential of a politically viable compromise.

With the week of 24 April designated by animal rights activists as 'world week for lab animals', increased public attention is expected. In Massachusetts, organizers say they plan to hold demonstrations aimed specifically at the Gillette Corporation because of the company's use of animals in the development and testing of its products.

In New York, for the third year in a row, protesters plan to target their demonstrations at New York University. Animal rights groups have singled out the research conducted by Ronald W. Wood, professor in the department of environmental medicine. Wood, who studies the effects of the inhalation of toxic substances including crack and cocaine, as well as organic solvents, uses rodents and some primates in his research. Last year's demonstrations in New York drew more than a thousand protesters.

Wood says he believes most are "well intentioned, but misguided". "My work", he says, "tries to provide information about very real human problems of drug abuse and occupational hazards."

Seth Shulman 